\title{
Tissue characterization following revascularization of immature dog teeth using different disinfection pastes
}

\section{Claudia Medianeira Londero PAGLIARIN(a) \\ Clacir de Lourdes Dotto LONDERO(b) Mara Cristina Santos FELIPPE(c) Wilson Tadeu FELIPPE(c) Cristiane Cademartori DANESI(d) Fernando Branco BARLETTA ${ }^{(e)}$}

\footnotetext{
(a) Universidade Federal de Santa Maria - UFSM, School of Dentistry, Department of Stomatology, Santa Maria, RS, Brazil.

(b) Universidade Federal de Santa Maria - UFSM, School of Dentistry, Dental Service, Santa Maria, RS, Brazil.

(c) Universidade Federal de Santa Catarina - UFSC, School of Dentistry, Department of Dentistry, Florianópolis, SC, Brazil.
}

(d) Universidade Federal de Santa Maria - UFSM, School of Dentistry, Department of Pathology, Santa Maria, RS, Brazil.

(e) Universidade Luterana do Brazil - ULBRA, School of Dentistry, Department of Endodontics, Canoas, RS, Brazil.

Declaration of Interests: The authors certify that they have no commercial or associative interest that represents a conflict of interest in connection with the manuscript.

Corresponding Author: Claudia Londero Pagliarin E-mail: clpagliarin@gmail.com

DOI: 10.1590/1807-3107BOR-2016.vol30.0074

Submitted: Aug 26, 2015

Accepted for publication: Dec 03, 2015

Last revision: Apr 28, 2016

\begin{abstract}
Revascularization of immature teeth with necrotic pulps traditionally involves the use of triple antibiotic paste, which may sometimes lead to undesirable complications. The objective of this study was to assess tissue repair in immature dog teeth with apical periodontitis subjected to revascularization, comparing two different pastes used for root canal disinfection. Apical periodontitis was induced in $30 \mathrm{dog}$ premolars. Teeth were randomly divided into three experimental groups: root canals filled with triple antibiotic paste $(n=10)$; root canals filled with $1 \%$ propolis paste $(n=10)$; and no medication $(n=10)$. An additional group $(n=10$, no intervention) was used as control. After 7 months, the jaws were histologically evaluated for the following variables: newly formed mineralized tissue (present/absent); vital tissue in the canal space (absent/periodontal ligament-like/pulp-like); apical extension of root (present/absent); and severity of inflammatory process (absent/mild/moderate/severe). There were no statistically significant differences among the experimental groups in new mineralized tissue formation and apical root development. The formation of vital tissue in the canal space, in turn, was statistically different between the triple paste and propolis groups: vital tissues were present in all revascularized teeth disinfected with propolis paste $(100 \%)$, compared to $71 \%$ of those disinfected with the triple paste. Severity of inflammatory process was different between the triple paste and no medication groups. The new tissues formed onto canal walls and in the root canal space showed characteristics of cementum and periodontal ligament, respectively. Propolis may have some advantages over the triple paste for the revascularization of immature teeth.
\end{abstract}

Keywords: Endodontics; Tooth Apex; Propolis; Guided Tissue Regeneration, Periodontal.

\section{Introduction}

The results available in the literature, originating from both controlled animal studies ${ }^{1,2}$ and clinical case reports, ${ }^{3,4}$ leave no doubt that revascularization procedures are an important and feasible option in the treatment of immature teeth with necrotic pulps and periapical lesions. Revascularization allows for continued root development, in both length and thickness, reinforcing the radicular structure, and has the potential to decrease the risks of fracture, ${ }^{3,4,5}$ treatment duration, and cost. ${ }^{6}$ 
The success of revascularization procedures depends primarily on adequate infection control in the canal: an effective antimicrobial protocol should be adopted. ${ }^{7}$ The intracanal medication mostly used for root canal disinfection is the triple antibiotic paste, ${ }^{8}$ composed of ciprofloxacin, metronidazole, and minocycline. Even though this combination of drugs has shown to be effective against bacteria commonly found in root canals, both in vitro ${ }^{8,9}$ and in vivo, ${ }^{2,10}$ some shortcomings have been described, e.g., tooth discoloration, ${ }^{2,11,12,13}$ bacterial resistance, ${ }^{14,15}$ and allergic reactions. ${ }^{16,17}$ More recently, demineralization of radicular dentin ${ }^{18}$ and a toxic effect on cells from the dental pulp and apical papilla ${ }^{19}$ have also been reported. Finally, minocycline has been associated with angiogenesis inhibition. ${ }^{20}$

Propolis has been widely investigated in dentistry for its potential use as an intracanal medication, especially because of its antibacterial, antifungal, antiviral, anti-inflammatory, and antioxidant properties. ${ }^{21,22,23}$ The antibacterial activity of propolis has been primarily associated with the presence of flavonoids. ${ }^{24,25}$ Another important characteristic of propolis is its biocompatibility, or the ability to maintain cell viability, as evidenced previously. ${ }^{26,27}$

Taking into consideration the disadvantages associated with the triple antibiotic paste and the emergence of propolis as an intracanal medication, the objective of this study was to assess tissue repair in immature dog teeth with necrotic pulps and apical periodontitis subjected to revascularization treatment, comparing these two pastes used for root canal disinfection.

\section{Methodology}

This study conforms with the ARRIVE Guidelines and was approved by the Research Ethics and Animal Welfare Committee of Universidade Federal de Santa Catarina - UFSC, Florianópolis, southern Brazil. The second, third, and fourth mandibular premolars and the second and third maxillary premolars of four Beagle dogs aged 5 to 6 months were used (total of 40 teeth, 80 roots).

Animals received pre-anesthesia with $0.5 \mathrm{mg} / \mathrm{kg}$ of acepromazine hydrochloride (Ouro Fino, Cravinhos, Brazil) and $4 \mathrm{mg} / \mathrm{kg}$ of pethidine (Cristália, São Paulo,
Brazil) via intramuscular injection. After 10 minutes, the animals were cannulated using a 22G catheter and administered $0.9 \%$ saline solution as maintenance fluid at $10 \mathrm{~mL} / \mathrm{kg} / \mathrm{h}$. Subsequently, anesthesia was induced using intravenous propofol (Cristália) at $5 \mathrm{mg} / \mathrm{kg}$. Animals were intubated using an endotracheal tube with cuff and maintained under anesthesia with isoflurane (Cristália).

Preoperative radiographs were obtained to confirm the presence of open apices. Following endodontic access of 30 teeth and working length determination (tooth length minus $1 \mathrm{~mm}$ ), pulp tissues were removed using \#60 K-files (Dentsply Maillefer, Ballaigues, Switzerland). Files were advanced to the apical limit, rotated to move the pulp, and then removed. Subsequently, \#60 Hedströen files (Dentsply Maillefer) calibrated at the same length were used to remove residual pulp tissues. Canals were irrigated with $2.5 \mathrm{~mL}$ of distilled water. Once hemostasis was established, a cotton pellet was placed at the canal entrance. Teeth were left open (no coronal sealing) for 3 weeks to allow root canal contamination.

At the end of 3 weeks, the animals were anesthetized once again and the canals re-entered under aseptic conditions. Teeth were irrigated with $10 \mathrm{~mL}$ of $2.5 \%$ sodium hypochlorite (Farmácia de Manipulação Nova Derme, Santa Maria, Brazil) to remove debris accumulated inside the root canals. After irrigation, canals were dried using sterile paper points and divided into three experimental groups, as follows: canals (10 teeth, 20 roots) filled with triple antibiotic paste (Farmácia de Manipulação Nova Derme) composed of ciprofloxacin, metronidazole, and minocycline $(20 \mathrm{mg}$ of each antibiotic per $\mathrm{mL}$ with sterile saline solution); canals (10 teeth, 20 roots) filled with $1 \%$ propolis paste in a glycerin vehicle (Farmácia de Manipulação Nova Derme); no intracanal medication (10 teeth, 20 roots). The 10 teeth (20 roots) included in the negative control group were not subjected to any intervention, to allow the physiological development of the root. Figure 1 shows the experimental design and study procedures.

In the triple antibiotic and propolis groups, pastes were applied to the cementoenamel junction using a $27 \mathrm{G}$ needle calibrated to $2 \mathrm{~mm}$ short of the working length. A sterile cotton pellet was placed 


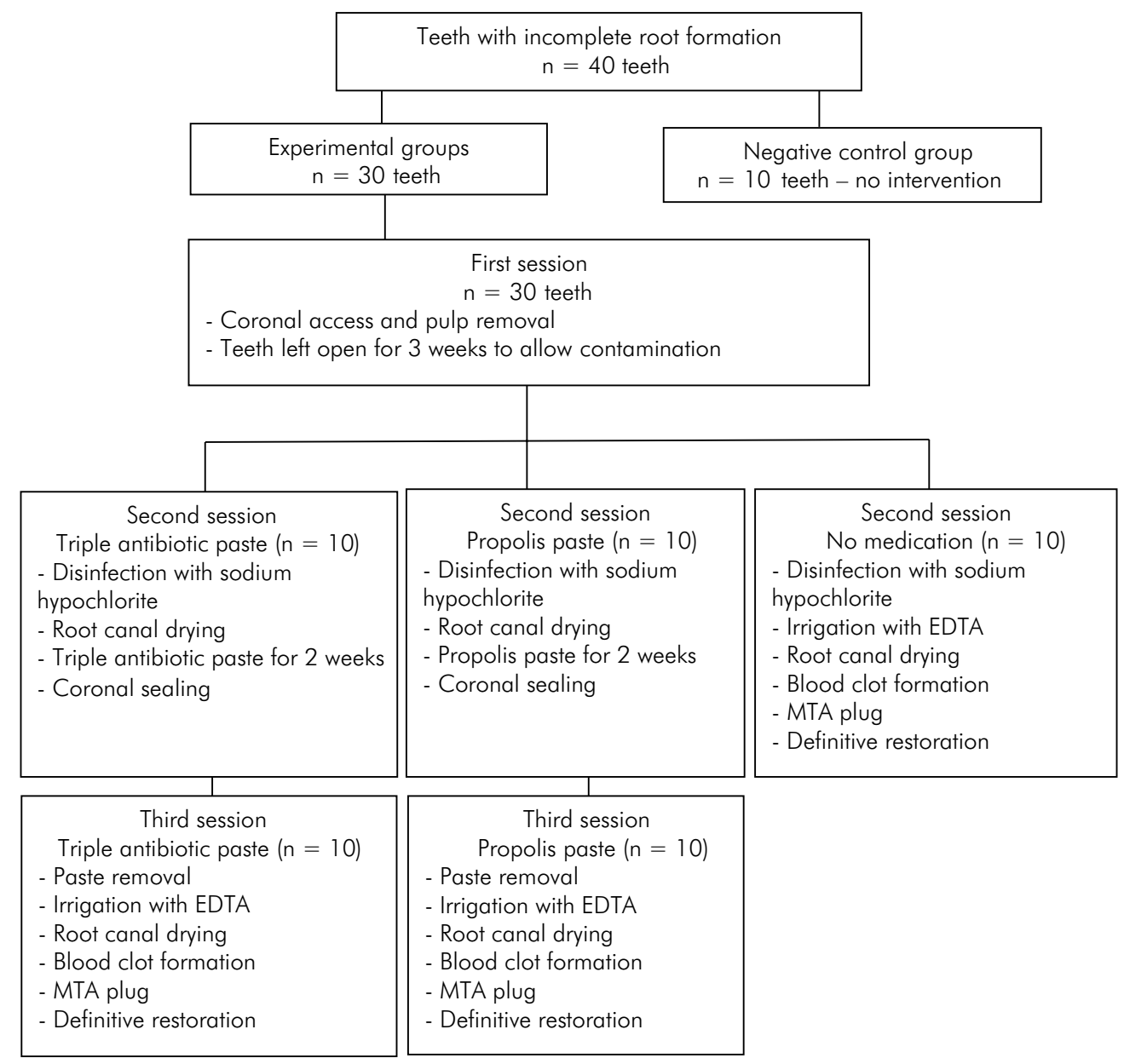

Figure 1. Experimental design and study procedures.

on top of the pastes, and teeth were temporarily sealed with intermediate restorative material (IRM) (Dentsply Maillefer). After 2 weeks, following the same anesthesia and asepsis protocols, temporary restorations were removed and the teeth irrigated with $10 \mathrm{~mL}$ of $2.5 \%$ sodium hypochlorite and $10 \mathrm{~mL}$ of saline solution. Subsequently, canals were irrigated with 17\% EDTA for 3 min and then dried with sterile absorbent paper points. A \#30 K-file (Dentsply Maillefer) was advanced into the root canal to $2 \mathrm{~mm}$ beyond the root length to stimulate bleeding in the periapical tissue and allow the formation of a blood clot inside the canal. With the aid of a sterile cotton pellet soaked in saline solution, the clot was gently pressed 1 to $2 \mathrm{~mm}$ apical to the cementoenamel junction for approximately 15 minutes.

In the 10 teeth ( 20 roots) of the no medication group, in the same session in which disinfection was carried out with $2.5 \%$ sodium hypochlorite, root canals were immediately irrigated with EDTA; after drying, blood clot formation was induced as described above.

In all three experimental groups, a 1 to $2 \mathrm{~mm}$ thick plug of white fast-setting MTA was placed on top of the blood clot (Angelus Indústria de Produtos Odontológicos Ltda., Londrina, Brazil). Then, definitive amalgam restorations were performed (DFL Alloy Indústria e Comércio S.A., Rio de Janeiro, Brazil).

The animals received medication after all surgical procedures and were constantly monitored by the team of veterinarians of the laboratory animal house.

After 7 months, animals were euthanized by perfusion. Their jaws were removed, dissected, and fixed in $10 \%$ formaldehyde. Following decalcification in $50 \%$ formic acid and $5 \mathrm{~N}$ sodium citrate, specimens were reduced, embedded in paraffin, 
and longitudinally sectioned along the tooth's long axis until reaching the apical foramen. Then, approximately $6-\mu \mathrm{m}$ thick semiserial sections were obtained and stained with hematoxylin and eosin (HE).

Histological sections were analyzed under light microscopy (Olympus BX41, Olympus, Tokyo, Japan) by two examiners previously trained to assess the following parameters: ${ }^{10}$

1. Apical extension of the root: present, when newly formed mineralized tissue (MT) was found in the apical region, promoting increase of root length; or absent, when no new MT deposition was observed in the apical region;

2. Presence or absence of vital tissue in the root canal space, identifying the type of tissue formed: pulp-like, layer of odontoblasts underlying the dentin surface; or periodontal ligament-like, fibrous elements (collagen fibers, Sharpey fibers), presence of forming cells (osteoblasts, cementoblasts, and fibroblasts), resorption cells, and other cells, such as macrophages, mastocytes, and epithelial cell rests of Malassez;

3. Presence or absence of newly formed MT on the lateral walls of root canals, identifying the type of tissue formed: dentin-like, characterized by the presence of dentinal tubules; cementum-like, characterized by the absence of dentinal tubules and adherence onto the dentin, with or without embedded cells; or bone-like, characterized by the presence of haversian canals with uniformly distributed osteocyte-like cells; and

4. Inflammatory reaction: absent, absence of inflammatory cells; mild, small number of dispersed inflammatory cells; moderate, focal accumulations of inflammatory cells; or severe, intense inflammatory infiltrate and tissue alterations.

Intra- and inter-examiner agreement was assessed using Cohen's kappa, calculated for each parameter by repeating assessments of $10 \%$ of the sample.

\section{Statistical analysis}

Categorical data were expressed as percentages. The significance of findings was determined using
Fisher's exact test. Post-hoc comparisons were adjusted using Finner's method. Significance was set at $\alpha=0.05$. Data were analyzed using the Statistical Package for the Social Sciences (SPSS) version 21.0 and WinPEPI version 10.5 .

\section{Results}

Intra- and inter-examiner agreement yielded Kappa $=1$ for all parameters, except inflammatory reaction, where scores were 0.86 and 0.82 , respectively.

Three teeth (six roots) were lost in the triple antibiotic paste group: one due to periodontal disease, one during histological processing, and one because the MTA plug moved apically, preventing assessment of the parameters under investigation. In the propolis paste group, two teeth (four roots) were lost during histological processing. In the no medication group, two teeth (four roots) were lost during histological processing and one tooth (two roots) due to periodontal disease. The results obtained for the different parameters assessed are shown in Table. All roots in the negative control group (no intervention) showed physiological root development.

\section{Histological analysis}

\section{New mineralized tissue formation on dentinal walls and in root canal space}

All experimental groups showed two types of newly formed MT, one adhered to the dentinal walls and another in the root canal space (Figures 2 and 3 ).

The tissue formed on the dentinal walls showed histological characteristics similar to radicular cementum (cementum-like MT): avascular tissue, with cells embedded in the matrix (cementocyte-like cells) and surface (cementoblast-like cells). In most specimens, this tissue was a continuity of the cementum of the external radicular surface and was responsible for the increased thickness and apical extension of the root (Figure 4).

The tissue formed in the canal space showed histological characteristics similar to bone tissue (bone-like MT): vascularized, matrix with embedded cells (osteocyte-like), osteoblast-like cells on the tissue surface, and medullary spaces (Figure 3). 
Table. Results obtained in the different groups.

\begin{tabular}{|c|c|c|c|c|c|}
\hline \multirow{2}{*}{ Parameter } & Triple antibiotic paste & Propolis paste & No medication & Negative control & \multirow{2}{*}{$\mathrm{p}$} \\
\hline & $(n=14)$ & $(n=16)$ & $(n=14)$ & $(n=20)$ & \\
\hline Apical extension of root & & & & & 0.002 \\
\hline Present & $8(57.1)^{a}$ & $13(81.2)^{\mathrm{ab}}$ & $8(57.1)^{a}$ & $20(100.0)^{b}$ & \\
\hline Absent & $6(42.9)$ & $3(18.8)$ & $6(42.9)$ & $0(0.0)$ & \\
\hline Vital tissue & & & & & $<0.001$ \\
\hline Absent & $4(28.6)^{a}$ & $0(0.0)^{b}$ & $3(21.4)^{a b}$ & $0(0.0)^{c}$ & \\
\hline Periodontal ligament-like & $10(71.4)$ & $16(100.0)$ & $11(78.6)$ & $0(0.0)$ & \\
\hline Pulp-like & $0(0.0)$ & $0(0.0)$ & $0(0.0)$ & $20(100.0)$ & \\
\hline Newly formed mineralized tissue & & & & & $<0.001$ \\
\hline Absent & $5(35.7)^{\mathrm{a}}$ & $2(12.5)^{a}$ & $4(28.6)^{a}$ & $0(0.0)^{b}$ & \\
\hline Cementum-like & 9 (64.3) & $14(87.5)$ & $10(71.4)$ & $0(0.0)$ & \\
\hline Dentin-like & $0(0.0)$ & $0(0.0)$ & $0(0.0)$ & $20(100.0)$ & \\
\hline Bone-like & $0(0.0)$ & $0(0.0)$ & $0(0.0)$ & $0(0.0)$ & \\
\hline Inflammatory reaction & $\mathrm{n}=10^{*}$ & $n=16$ & $\mathrm{n}=11^{*}$ & $\mathrm{n}=20$ & $<0.001$ \\
\hline Absent & $1(10.0)^{a}$ & $3(18.8)^{a b}$ & $6(54.5)^{b}$ & $20(100.0)^{c}$ & \\
\hline Mild & $4(40.0)$ & 3 (18.8) & 3 (27.3) & 0.0 & \\
\hline Moderate & $0(0.0)$ & 6 (37.4) & 2 (18.2) & 0.0 & \\
\hline Severe & $5(50.0)$ & $4(25.0)$ & $0(0.0)$ & 0.0 & \\
\hline
\end{tabular}

Data are expressed as absolute numbers (percentages). Different letters indicate significant differences (Fisher's exact test) according to post-hoc comparisons adjusted using Finner's method. * Different $\mathrm{n}$ values in groups 1 and 3 (inflammatory reaction) due to the absence of vital tissue in four and three specimens, respectively, preventing assessment of this variable.

Bone-like MT formation was variable, and in some specimens was a continuity of the periapical bone tissue and of the tissue formed onto dentin (cementum-like MT).

Despite the absence of statistical differences between the three experimental groups, specimens in the propolis paste group showed a greater and more uniform deposition of cementum-like MT onto dentinal walls. Moreover, in many specimens from the no medication group, cementum-like MT deposition nearly obstructed the root canal lumen, whereas in other specimens from the same group deposition was less evident.

\section{Presence of vital tissue in root canal space}

All experimental groups showed vital tissue in the root canal space, with histological characteristics similar to periodontal ligament. In some specimens, there was ingrowth of the periodontal ligament into the root canal space; in some histological sections, collagen fibers resembling Sharpey fibers were observed anchored in cementum-like tissue. Pulp tissue inside the canal was not observed in any specimen from any experimental group.
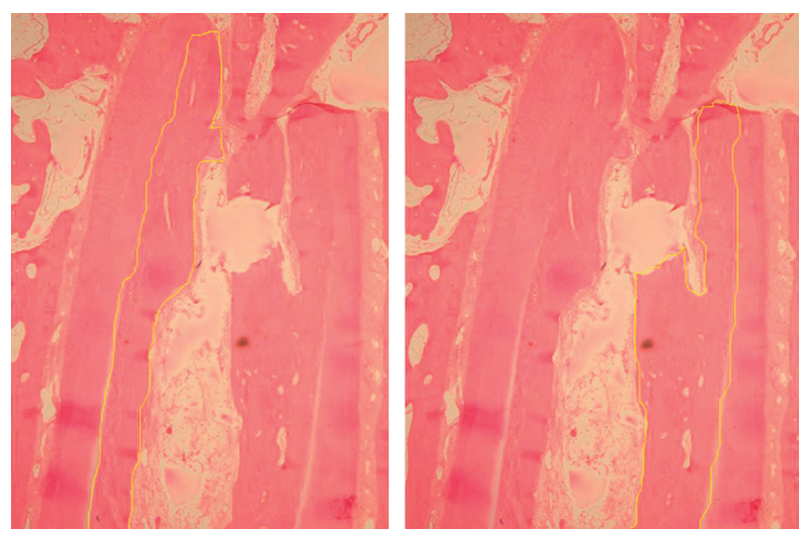

Figure 2. Photomicrograph of a specimen from the triple antibiotic paste group showing deposition of cementum-like mineralized tissue onto dentin (yellow lines). $20 \times$ magnification. 


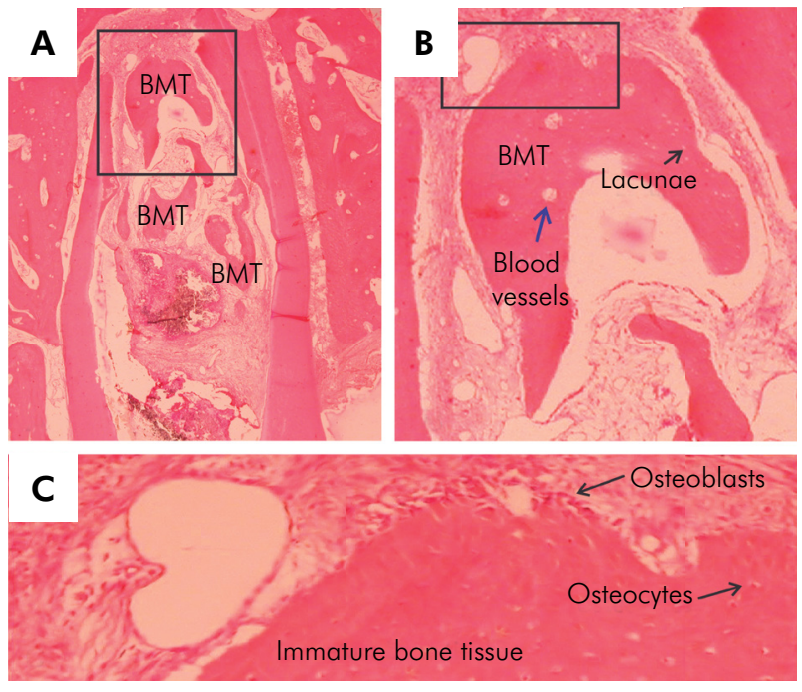

Figure 3. (A) Photomicrograph of a specimen from the propolis paste group showing bone-like mineralized tissue (BMT) formation in the root canal space $(20 \times$ magnification). (B) Detail of the area shown in A, evidencing the presence of lacunae hosting osteocytes (black arrow) and blood vessels (blue arrow). (C) Detail of the area shown in B, evidencing presence of osteocyte-like cells embedded in the matrix and osteoblast-like cells embedded in the tissue surface.

\section{Apical extension of root}

Even though inter-group differences were not significant, the propolis paste group showed a higher number of roots with apical extension. In all experimental groups, there were some roots in which MT formation closed the root apex, and others in which the apex remained open.

\section{Inflammatory reaction}

Another finding common to all experimental groups was the presence of inflammatory processes of different levels of severity in the new vital tissue formed in the root canal space. Inflammatory cells were present especially in the cervical third of the root canal, adjacent to the MTA plug.

\section{Discussion}

Triple antibiotic paste is a well-established medication for rootcanal disinfection in revascularization procedures. Despite its effectiveness promoting disinfection and creating the necessary conditions for repair, several studies have described undesirable outcomes associated with its use, including discoloration of the tooth structure

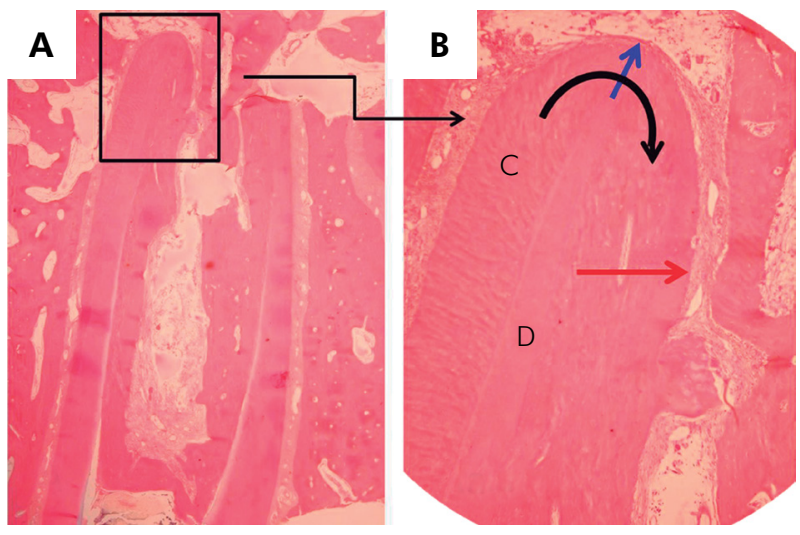

Figure 4. (A) Photomicrograph of a specimen from the triple antibiotic paste group (20× magnification). (B) Detail of the area shown in $A$, evidencing cementum-like mineralized tissue formation, responsible for increased thickness (red arrow) and greater apical extension (blue arrow) of root. Note ingrowth of cementum from the external into the internal radicular surface (black arrow). C: Cementum; D: Dentin.

caused by minocycline, ${ }_{11}^{11}$ demineralization of the radicular dentin, increasing the risk of fracture, ${ }^{18}$ and toxic effects on pulp and apical papilla cells observed in culture. ${ }^{11,19,28}$ Taking into consideration these disadvantages, the present study assessed tissue repair in immature dog teeth with necrotic pulps and apical periodontitis while using both triple antibiotic paste and propolis paste for root canal disinfection.

Propolis is a resinous substance that honey bees collect from several plants and use to cover and seal unwanted open spaces in the hive, so as to keep a low concentration of bacteria and fungi. The main chemical components of propolis areflavonoids, phenolics, and aromatic compounds. ${ }^{29}$ The use of propolis as an alternative intracanal medication has been suggested by several authors $\mathrm{s}^{21,22,30}$ due to its antimicrobial properties and biocompatibility ${ }^{26,27}$-features that have probably contributed to the findings obtained in our study. The goal of the present study was to contribute to the development of a new, more biological treatment protocol, with stronger antimicrobial effects and lower toxic effects.

None of the specimens in the sample showed pulp- or dentin-like tissue formation. Similar results have been reported previously. ${ }^{1,19,31}$ According to those previous studies, undifferentiated cells from the apical papilla may necrose as a result of the severe infection induced and/or of the cytotoxic effect of the triple antibiotic paste used for root canal disinfection. 
In addition, in line with previous studies, ${ }^{1,32}$ the specimens showed the formation of two types of MT inside the canal: one deposited onto dentinal walls, similar to radicular cementum (cementum-like MT), and another in the root canal space, similar to bone (bone-like MT). Yamauchi et al. ${ }^{33}$ characterized the two tissues found in their sample using histochemical and immunohistochemical analysis and also showed that the tissue lining the dentin was different from dentin and bone, but similar to cementum. They also reported that the islands of MT formed in the root canal space resembled bone matrix. It is likely that the cells responsible for the formation of these new tissues originate from bone marrow mesenchymal stem cells and periodontal ligament stem cells. According to Lovelace et al., ${ }^{34}$ these cells are delivered into the root canal when bleeding is induced by overinstrumentation.

In one specimen from the propolis paste group, bone-like MT was a continuity of cementum-like MT. This finding was probably a result of the longer follow-up time in our study (7 months) when compared with previous ones with similar methodologies (usually the study period is of approximately 3 months). ${ }^{1,10,33,35}$ According to Yamauchi et al., ${ }^{32}$ in many cases, cementum-like MT formed on the dentin surface is thicker than the natural layer of radicular cementum; it remains to be known whether deposition of this type of tissue would continue until obstructing the canal lumen with a longer follow-up time. Possibly, in the long term, the direct contact between the two types of MT could cause replacement resorption inside the canal, in which cementum-like MT would be resorbed and replaced with bone-like MT as part of a bone remodeling process, similar to the replacement resorption process observed after traumatic injuries (Figure 5).

Despite the absence of significant differences between the experimental groups regarding new MT deposition, the histological findings observed indicated that the use of propolis paste increased tissue deposition on dentinal walls, in some cases almost obstructing the root canal space. This finding is probably explained by the minimum toxicity of propolis and the consequent stimulation of cell proliferation, a property previously demonstrated by several authors. ${ }^{26,27}$

An interesting histological finding was the lower deposition of new MT in the triple antibiotic paste group

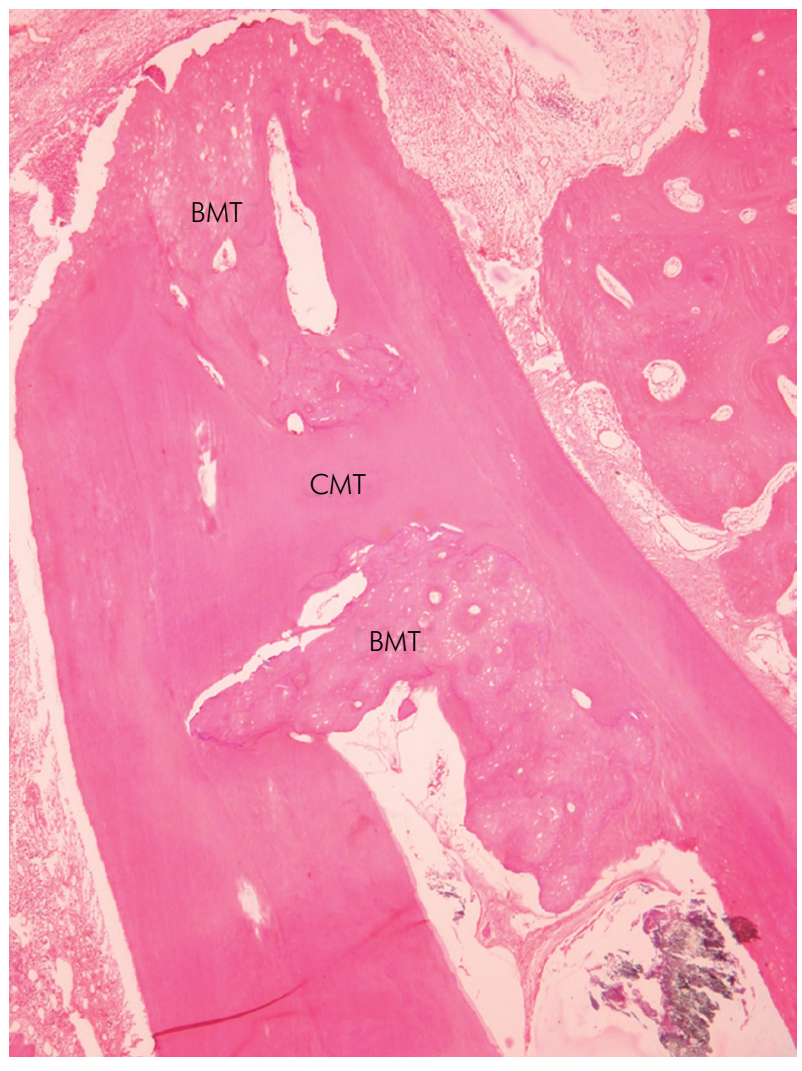

Figure 5. Photomicrograph of a specimen from the propolis paste group showing bone-like mineralized tissue (BMT) in contact with cementum-like mineralized tissue (CMT). $20 \times$ magnification.

when compared with the no medication group. This could probably be explained by the toxic effect of the triple paste on cells involved in the repair process. ${ }^{18,19,28}$ Phumpatrakom and Srisuwan ${ }^{36}$ have shown that, even at low concentrations, the triple paste affects cell proliferation in the pulp and apical papilla and the formation of mineralized matrices. Also, as suggested by Silva et al., ${ }^{35}$ intracanal use of antibiotic medications is apparently not essential to MT formation. According to those authors, the use of triple antibiotic paste was associated with poorer results in terms of MT formation, apical development, and repair of periapical tissues when compared with a group not using the paste.

With regard to apical extension of the root, characterized by deposition of cementum-like tissue, the present results did not show significant differences between the experimental groups. In fact, the results obtained in the propolis paste group were similar to those of the no intervention group. Regardless of 
group allocation, some specimens showed apical extension of the root and apex closure as a result of cementum-like MT deposition, while in other specimens the apex remained open.

According to the present findings, the presence of vital tissue inside the root canals was significantly higher in the propolis paste than in triple antibiotic paste group. Again, this finding is most likely due to the fact that propolis paste has minimum toxicity and therefore induces cell proliferation, ${ }^{26,27}$ as also reported by other authors. ${ }^{19,28}$ Still with regard to this parameter, no significant differences were found between the propolis paste and the no medication groups. This finding may be due to the disinfection promoted by the use of sodium hypochlorite and the delivery of undifferentiated mesenchymal cells with the blood clot.

Severity of the inflammatory process present in the canal space showed significant differences between the triple antibiotic paste and the no medication groups. Whereas in the triple antibiotic paste group $50 \%$ of the samples showed severe inflammatory reactions, in the no medication group most specimens (54.5\%) did not show signs of inflammation - when present, inflammation in was classified as mild (27.3\%) or moderate (18.2\%). It is likely that the more severe inflammatory process observed in the triple antibiotic paste group is due to the irritation caused by the antibiotic agents present in the triple paste. Similar results were reported by Silva et al. ${ }^{35}$ and Pereira et al. ${ }^{37}$ The latter authors, ${ }^{37}$ characterizing rat subcutaneous tissue response after the use of triple antibiotic paste, observed a severe, persistent inflammatory process and no repair, confirming the paste's cytotoxicity. Also, it is possible that the paste concentration used in this study $(20 \mathrm{mg} / \mathrm{mL})$ has caused the less favorable results obtained in the triple antibiotic group with regard to severity of the inflammatory process and vital tissue formation in the root canal space.

The assessment of tooth discoloration was beyond the scope of the present study. Notwithstanding, the discoloration/darkening observed in all specimens of the triple antibiotic paste group deserves mention. Similar results have been reported by Lenherr et al. ${ }^{38}$ while investigating the potential of endodontic materials to induce changes in tooth color. In those authors' study, the most severe change in color occurred after the use of triple antibiotic paste. Changes in color are caused by the presence of minocycline in the paste, a semisynthetic tetracycline derivative.

We also observed coronal discoloration close to the gingival margin in the groups not using triple antibiotic paste as intracanal medication. This change in color is related to the MTA plug placed on top of the blood clot. According to the literature, this discoloration is caused by the interaction between the bismuth oxide present in MTA and the collagen present in dental tissues. ${ }^{39,40}$

The discoloration provoked by the paste, especially in anterior teeth, is a major disadvantage of this medication: by compromising esthetics, such change in tooth color may cause important psychological and social effects and have a negative impact on the quality of life of young patients.

\section{Conclusion}

The results of this study suggest that propolis paste may be a feasible substitute for triple antibiotic paste in the disinfection of roots canals of immature teeth with necrotic pulps, with the advantage of not causing changes in tooth color. The new tissues formed inside the root canal showed characteristics similar to cementum, bone, and periodontal ligament.

\section{References}

1. Wang X, Thibodeau B, Trope M, Lin LM, Huang GT.

Histologic characterization of regenerated tissues in canal space after the revitalization/revascularization procedure of immature dog teeth with apical periodontitis. J Endod. 2010;36(1):56-63. doi:10.1016/j.joen.2009.09.039

2. Windley W 3rd, Teixeira F, Levin L, Sigurdsson A, Trope M. Disinfection of immature teeth with a triple antibiotic paste. J Endod. 2005;31(6):439-43. doi:10.1097/01.don.0000148143.80283.ea

3. Banchs F, Trope M. Revascularization of immature permanent teeth with apical periodontitis: new treatment protocol? J Endod. 2004;30(4):196-200. doi:10.1097/00004770-200404000-00003

4. Chueh LH, Huang GT. Immature teeth with periradicular periodontitis or abscess undergoing apexogenesis: a paradigm shift. J Endod. 2006;32(12):1205-13. doi:10.1016/j.joen.2006.07.010

5. Iwaya SI, Ikawa M, Kubota M. Revascularization of an immature permanent tooth with apical periodontitis 
and sinus tract. Dent Traumatol. 2001;17(4):185-7.

doi:10.1034/j.1600-9657.2001.017004185.x

6. Shah N, Logani A, Bhaskar U, Aggarwal V. Efficacy of revascularization to induce apexification/apexogensis in infected, nonvital, immature teeth: a pilot clinical study. J Endod. 2008;34(8):919-25; Discussion 1157. doi:10.1016/j.joen.2008.05.001. Erratum in J Endod. 2008;34(10):1263.

7. Trope M. Clinical management of the avulsed tooth: present strategies and future directions. Dent Traumatol. 2002;18(1):1-11. doi:10.1046/j.1600-4469.2001.00001.x

8. Hoshino E, Kurihara-Ando N, Sato I, Uematsu H, Sato $\mathrm{M}$, Kota K, et al. In-vitro antibacterial susceptibility of bacteria taken from infected root dentine to a mixture of ciprofloxacin, metronidazole and minocycline. Int Endod J. 1996;29(2):125-30. doi:10.1111/j.1365-2591.1996.tb01173.x

9. Sato I, Ando-Kurihara N, Kota K, Iwaku M, Hoshino E. Sterilization of infected root-canal dentine by topical application of a mixture of ciprofloxacin, metronidazole and minocycline in situ. Int Endod J. 1996;29(2):118-24. doi:10.1111/j.1365-2591.1996.tb01172.x

10. Thibodeau B, Trope M. Pulp revascularization of a necrotic infected immature permanent tooth: case report and review of the literature. Pediatr Dent. 2007;29(1):47-50.

11. Kim JH, Kim Y, Shin SJ, Park JW, Jung IY. Tooth discoloration of immature permanent incisor associated with triple antibiotic therapy: a case report. J Endod. 2010;36(6):1086-91. doi:10.1016/j.joen.2010.03.031

12. Ordinola-Zapata R, Bramante CM, Minotti PG, Cavenago BC, Garcia RB, Bernardineli N, et al. Antimicrobial activity of triantibiotic paste, $2 \%$ chlorhexidine gel, and calcium hydroxide on an intraoral-infected dentin biofilm model. J Endod. 2013;39(1):115-8. doi:10.1016/j.joen.2012.10.004

13. Yang J, Zhao Y, Qin M, Ge L. Pulp revascularization of immature dens invaginatus with periapical periodontitis. J Endod. 2013;39(2):288-92. doi:10.1016/j.joen.2012.10.017

14. Eickholz P, Kim TS, Bürklin T, Schacher B, Renggli $\mathrm{HH}$, Schaecken MT, et al. Non-surgical periodontal therapy with adjunctive topical doxycycline: a double-blind randomized controlled multicenter study. J Clin Periodontol. 2002;29(2):108-17. doi:10.1034/j.1600-051x.2002.290204.x

15. Slots J. Selection of antimicrobial agents in periodontal therapy. J Periodontal Res. 2002;37(5):389-98. doi:10.1034/j.1600-0765.2002.00004.x

16. Isik SR, Karakaya G, Erkin G, Kalyoncu AF. Multidrug-induced erythema multiforme. J Investig Allergol Clin Immunol. 2007;17(3):196-8.

17. Madsen JT, Thormann J, Kerre S, Andersen KE, Goossens A. Allergic contact dermatitis to topical metronidazole - 3 cases. Contact Dermat. 2007;56(6):364-6. doi:10.1111/j.1600-0536.2006.01064.x

18. Yassen GH, Chu TM, Eckert G, Platt JA. Effect of medicaments used in endodontic regeneration technique on the chemical structure of human immature radicular dentin: an in vitro study. J Endod. 2013;39(2):269-73. doi:10.1016/j.joen.2012.09.020

19. Chuensombat S, Khemaleelakul S, Chattipakorn S, Srisuwan T. Cytotoxic effects and antibacterial efficacy of a 3-antibiotic combination: an in vitro study. J Endod. 2013;39(6):813-9. doi:10.1016/j.joen.2012.11.041

20. Gilbertson-Beadling S, Powers EA, Stamp-Cole M, Scott PS, Wallace TL, Copeland J, et al. The tetracycline analogs minocycline and doxycycline inhibit angiogenesis in vitro by a non-metalloproteinase-dependent mechanism. Cancer Chemother Pharmacol. 1995;36(5):418-24. doi:10.1007/BF00686191

21. Awawdeh L, Al-Beitawi M, Hammad M. Effectiveness of propolis and calcium hydroxide as a short-term intracanal medicament against Enterococcus faecalis: a laboratory study. Aust Endod J. 2009;35(2):52-8. doi:10.1111/j.1747-4477.2008.00125.x

22. Kandaswamy D, Venkateshbabu N, Gogulnath D, Kindo AJ. Dentinal tubule disinfection with $2 \%$ chlorhexidine gel, propolis, morinda citrifolia juice, $2 \%$ povidone iodine, and calcium hydroxide. Int Endod J. 2010;43(5):419-23. doi:10.1111/j.1365-2591.2010.01696.x

23. Uzel A, Sorkun K, Onçağ O, Cogŭlu D, Gençay O, Salih B. Chemical compositions and antimicrobial activities of four different Anatolian propolis samples. Microbiol Res. 2005;160(2):189-95. doi:10.1016/j.micres.2005.01.002

24. Cushnie TP, Lamb AJ. Antimicrobial activity of flavonoids. Int J Antimicrob Agents. 2005;26(5):343-56. doi:10.1016/j.ijantimicag.2005.09.002

25. Hayacibara MF, Koo H, Rosalen PL, Duarte S, Franco $\mathrm{EM}$, Bowen $\mathrm{WH}$, et al. In vitro and in vivo effects of isolated fractions of Brazilian propolis on caries development. J Ethnopharmacol. 2005;101(1-3):110-5. doi:10.1016/j.jep.2005.04.001

26. Al-Shaher A, Wallace J, Agarwal S, Bretz W, Baugh D. Effect of propolis on human fibroblasts from the pulp and periodontal ligament. J Endod. 2004;30(5):359-61. doi:10.1097/00004770-200405000-00012

27. Gjertsen AW, Stothz KA, Neiva KG, Pileggi R. Effect of propolis on proliferation and apoptosis of periodontal ligament fibroblasts. Oral Surg Oral Med Oral Pathol Oral Radiol Endod. 2011;112(6):843-8. doi:10.1016/j.tripleo.2011.08.004

28. Ruparel NB, Teixeira FB, Ferraz CC, Diogenes A. Direct effect of intracanal medicaments on survival of stem cells of the apical papilla. J Endod. 2012;38(10):1372-5. doi:10.1016/j.joen.2012.06.018

29. Viuda-Martos M, Ruiz-Navajas Y, Fernández-López J, Pérez-Alvarez JA. Functional properties of honey, propolis, and royal jelly. J Food Sci. 2008;73(9):R117-24. doi:10.1111/j.1750-3841.2008.00966.x

30. Kayaoglu G, Ömürlü H, Akca G, Gürel M, Gençay Ö, Sorkun K, et al. Antibacterial activity of propolis versus 
conventional endodontic disinfectants against

Enterococcus faecalis in infected dentinal tubules.

J Endod. 2011;37(3):376-81. doi:10.1016/j.joen.2010.11.024

31. Gomes-Filho JE, Duarte PCT, Ervolino E, Bomfim

SRM, Abimussi CJX, Santos LMS, et al. Histologic characterization of engineered tissues in the canal space of closed-apex teeth with apical periodontitis. J Endod. 2013;39(12):1549-56. doi:10.1016/j.joen.2013.08.023

32. Yamauchi N, Yamauchi S, Nagaoka H, Duggan D, Zhong S, Lee SM, et al. Tissue engineering strategies for immature teeth with apical periodontitis. J Endod. 2011;37(3):390-7. doi:10.1016/j.joen.2010.11.010

33. Yamauchi N, Nagaoka H, Yamauchi S, Teixeira FB, Miguez $\mathrm{P}$, Yamauchi M. Immunohistological characterization of newly formed tissues after regenerative procedure in immature dog teeth. J Endod. 2011;37(12):1636-41. doi:10.1016/j.joen.2011.08.025

34. Lovelace TW, Henry MA, Hargreaves KM, Diogenes A. Evaluation of the delivery of mesenchymal stem cells into the root canal space of necrotic immature teeth after clinical regenerative endodontic procedure. J Endod. 2011;37(2):133-8. doi:10.1016/j.joen.2010.10.009

35. Silva LA, Nelson-Filho P, Silva RA, Flores DS, Heilborn C, Johnson JD, et al. Revascularization and periapical repair after endodontic treatment using apical negative pressure irrigation versus conventional irrigation plus triantibiotic intracanal dressing in dogs' teeth with apical periodontitis. Oral Surg Oral Med Oral Pathol Oral Radiol Endod. 2010;109(5):779-87. doi:10.1016/j.tripleo.2009.12.046

36. Phumpatrakom P, Srisuwan T. Regenerative capacity of human dental pulp and apical papilla cells after treatment with a 3-antibiotic mixture. J Endod. 2014;40(3):399-405. doi:10.1016/j.joen.2013.09.027

37. Pereira MS, Rossi MA, Cardoso CR, Silva JS, Silva LAB, Kuga MC, et al. Cellular and molecular tissue response to triple antibiotic intracanal dressing. J Endod. 2014;40(4):499-504. doi:10.1016/j.joen.2013.10.029

38. Lenherr P, Allgayer N, Weiger R, Filippi A, Attin T, Krastl G. Tooth discoloration induced by endodontic materials: a laboratory study. Int Endod J. 2012;45(10):942-9. doi:10.1111/j.1365-2591.2012.02053.x

39. Bortoluzzi EA, Araújo GS, Tanomaru JMG, Tanomaru-Filho M. Marginal gingiva discoloration by gray MTA: a case report. J Endod. 2007;33(3):325-7. doi:10.1016/j.joen.2006.09.012

40. Marciano MA, Costa RM, Camilleri J, Mondelli RF, Guimarães BM, Duarte MA. Assessment of color stability of white mineral trioxide aggregate angelus and bismuth oxide in contact with tooth structure. J Endod. 2014;40(8):1235-40. doi:10.1016/j.joen.2014.01.044 